\title{
The layered model of the Copahue geothermal reservoir, Argentina
}

\author{
Hernan Barcelona ${ }^{1,2^{*}} \mathbb{D}$, Daniel Yagupsky ${ }^{1}$ and Mariano Agusto ${ }^{1}$
}

\author{
${ }^{*}$ Correspondence: \\ h.lidenbrock@gmail.com \\ ${ }^{1}$ CONICET-IDEAN, Instituto \\ de Estudios Andinos, \\ Universidad de Buenos \\ Aires, Pabellón II, Nuñez, \\ C1428EHA Buenos Aires, \\ Argentina \\ Full list of author information \\ is available at the end of the \\ article
}

\begin{abstract}
An exhaustive review of the available data related to the reservoir of the volcanohosted Copahue geothermal system is presented. Reservoir interpretation to date suggests a vapor-dominated nature. However, the review provided reveals the limitations of this model, regarding the transition from shallow argillic to deep propylitic alteration zones, gas geothermometers calibrated to near-neutral pH environment, production tests, and low recharge of the feed zone, among the other features. We propose that a layered model with a shallow vapor zone above a fluid pressurized reservoir better accounts for the known features of the geothermal reservoir. Temperature profiles define the 800-m-thick upper thermal boundary that includes the impermeable clay cap. An argillic alteration layer (smectite + chlorite + illite + kaolinite) with low electric resistivity response, consistent with the presence of smectite, composes the clay cap. A shallow steam cap develops immediately below the impermeable layer. This vapor zone has $200-215^{\circ} \mathrm{C}$, low seismic activity, and high electrical resistivity, and is highlighted by the isothermal segment of the well logs. The bottom part of the reservoir is subjected to controversy because of the lack of direct measurements. The deep liquid-dominated reservoir has a temperature of $\sim 280^{\circ} \mathrm{C}$, develops below $1500 \mathrm{~m}$ depth under near-neutral $\mathrm{pH}$ condition, and probably has a pervasive propylitic alteration, and wairakite + laumontite + chlorite + epidote + prehnite + actinolite is the likely mineral assemblage. Pressure collapse might trigger the development of the shallow steam cap during deflation-inflation volcanic cycles or Pleistocene-to-recent tectonic deformation. This work points out the main weak points of the previous conceptual model, providing an alternative one based on the first comprehensive compilation of data of the Copahue reservoir. Further research, including a deep exploration drilling stage, is required to establish the physicochemical reservoir state precisely and to validate the proposed layered model.
\end{abstract}

Keywords: Copahue geothermal field, Geothermal reservoir, Exploration, Vapordominated, Liquid-dominated

\section{Introduction}

The definition of a conceptual model is essential during the feasibility stage of a geothermal project, given that it drives both surficial and underground exploration, constraining the inferences about the reservoir nature. Geothermal reservoirs are commonly classified as liquid- or vapor-dominated, based on the mobile phase. A reservoir steam fraction of 1 defines a vapor-dominated system, whereas a steam fraction from 1 to 0 defines a two-phase, liquid-dominated system. Each reservoir-type develops at different

(c) The Author(s) 2019. This article is distributed under the terms of the Creative Commons Attribution 4.0 International License (http://creativecommons.org/licenses/by/4.0/), which permits unrestricted use, distribution, and reproduction in any medium, provided you give appropriate credit to the original author(s) and the source, provide a link to the Creative Commons license, and indicate if changes were made. 
tectonic settings and shows different surficial manifestations, deep geological structures, and permeability conditions. These features, in turn, define the geometry of the system (e.g., Jolie et al. 2015; Moeck 2014, Stelling et al. 2016). Vapor-dominated systems display greater geothermal potential and have significant engineering benefits over liquiddominated ones. They require about a third of the mass flow rate to achieve the same power output of a power plant, accessing a two-phase reservoir at the same conditions of temperature and pressure (Zarrouk and Moon 2014; Dipippo 2016). Therefore, the reservoir conceptual model has to be carefully analyzed to avoid incorrect planning of the deep-drilling stage, inaccurate assessment of the resource, and to perform better risk and financial models to prevent a delay or cancelation of the project.

The complex nature of the geothermal systems and the limited surficial and underground data is the typical scenario at the initial drilling stages that substantially hampers the preliminary reservoir characterization in any tectonic environment. Moreover, the underground exploration stage is usually more difficult in compressive volcanic arcs. Such a complex setting characterizes the Southern Volcanic Zone of the Andes, in which only a few projects reached that development stage (Fig. 1a). The most relevant are El Tatio and Cerro Pabellon in Chile (Aravena et al. 2016; Vargas and PüschelLovengreen 2016), Laguna Colorada in Bolivia (Terceros 2000; Villarroel Camacho 2014), and currently Chachimbiro in Ecuador. The Cordón Caulle geothermal system in Chile is an excellent example of the inherent complexity of establishing a conceptual model in this setting. A steam-heated aquifer above a vapor-dominated reservoir model was first proposed, but a comparative analysis of geochemical data of hot springs, fumaroles, and borehole fluids discharge allowed to define a deep liquid-dominated reservoir (Sepúlveda et al. 2004; Sepúlveda 2006). In fact, vapor-dominated reservoirs are unique natural systems (White et al. 1971). Except for Larderello, Yellowstone, and a cluster of volcano-hosted vapor-dominated reservoirs in Indonesia, no other natural vapor-dominated reservoirs have been found, despite hundreds of geothermal systems having been drilled in young volcanic provinces around the world (Raharjo et al. 2016).

The Copahue volcano is part of the Southern Volcanic Zone. It is located at a latitude of $37.8^{\circ} \mathrm{S}$ at the Argentina-Chile border, a region with a complex tectonic setting (Zapata et al. 1999; Ramos and Folguera 2005; Cembrano and Lara 2009; Pérez-Flores et al. 2016). The volcano has shown intense activity for the last 250 years (Delpino and Bermúdez 1993, 2002; Naranjo and Polanco 2004; Petrinovic et al. 2014; Caselli et al. 2015; Folguera et al. 2016). Its northeastern flank hosts several fumaroles that define the Copahue geothermal field. This area was the target of the most advanced Argentinean geothermal project to date (Pesce 1989; JICA 1992; Fig. 1b, c). After the start of production, the discharge of dry steam suggested that the system was vapor-dominated (Nakanishi et al. 1995). Numerous works have assumed the vapor-dominated nature for the reservoir at the Copahue geothermal system (e.g., Nakanishi et al. 1995; Chiodini et al. 2015; Lundgren et al. 2017). However, a complete review of available data is needed to assess this hypothesis adequately.

This study aims to analyze the available data of the Copahue geothermal reservoir, testing the current conceptual model nature. To reach these goals, we performed an analysis of the geologic and tectonic setting, pressure and temperature profiles, geothermal manifestations and hydrothermal alteration, and fluid geochemistry, together with 


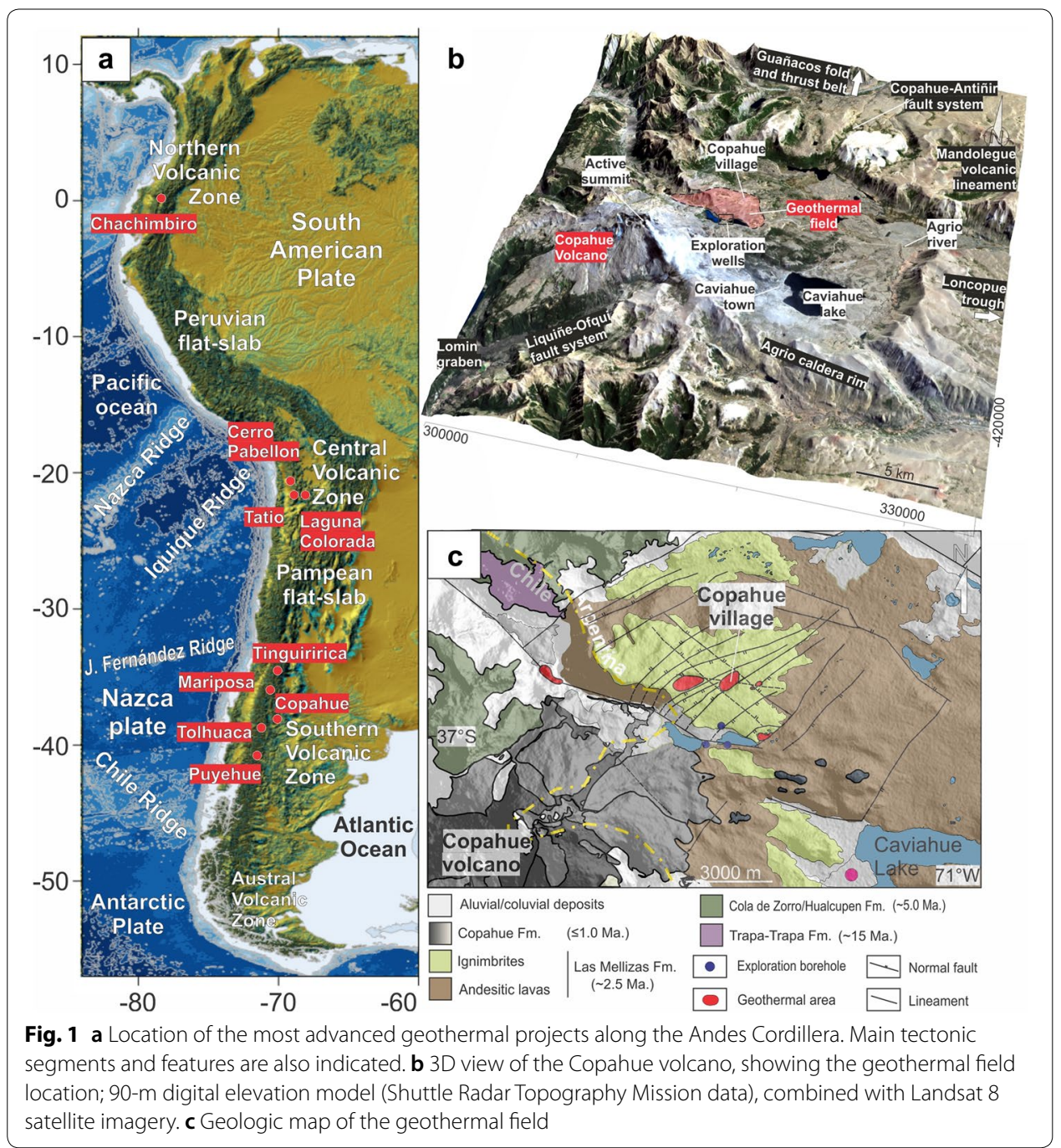

an evaluation of the production history of Copahue project. Finally, we propose a 1D layered conceptual model of the volcano-hosted geothermal reservoir.

\section{The pressure-depth profiles}

A typical feature of the vapor-dominated systems is the low pressure of the reservoir respective to the surrounding because of the lower weight of the vapor column in comparison with the hydrostatic column (White et al. 1971). On the other hand, liquid-dominated reservoirs have the typical pressure profile with an almost hydrostatic gradient. Thus, a general overview of the pressure vs. depth paths is useful for comparison between Copahue and the rest of the vapor-dominated reservoirs.

Figure 2 shows the pressure-depth profiles for the most distinguished vapor-dominated geothermal systems worldwide. What stands out in the figure is the roughly constant pressure path of The Geysers and Larderello, the largest developed vapordominated systems. While The Geysers is located at a transform boundary related to the cancelation of a subduction system (Dickinson and Snyder 1979), Larderello is located 


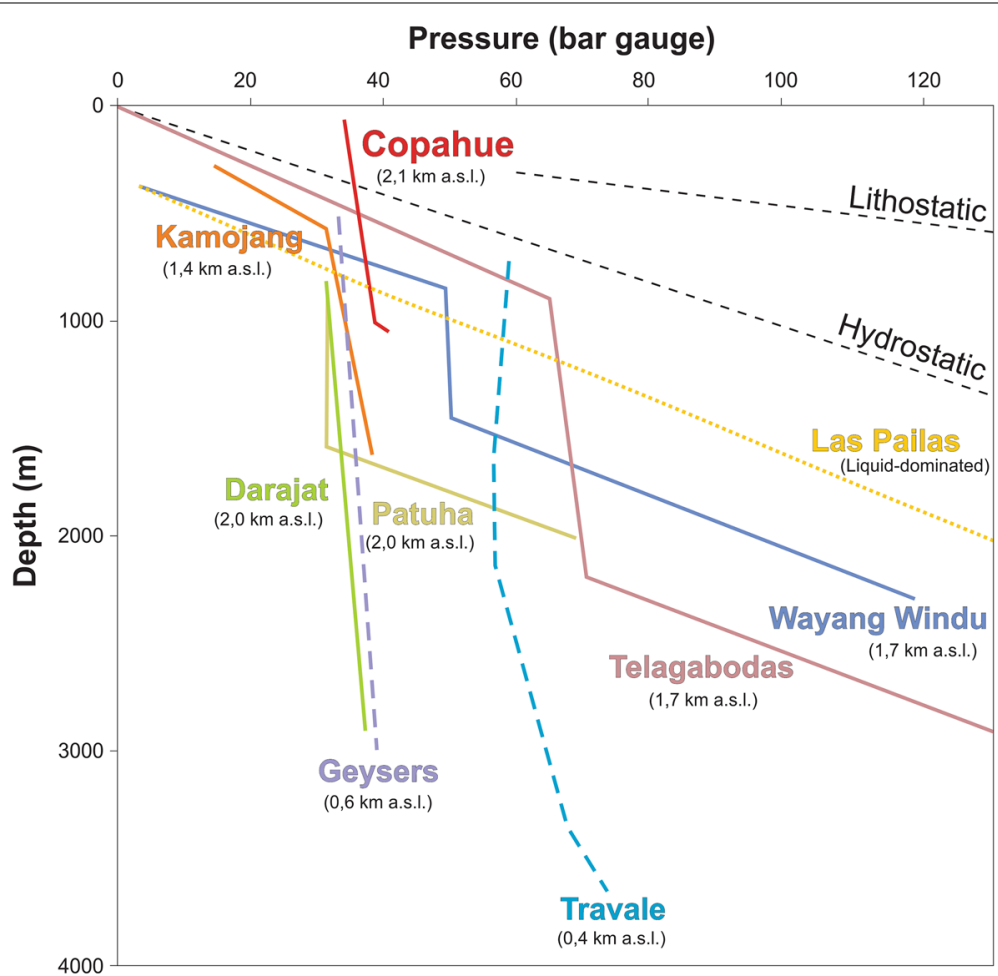

Fig. 2 Stable downhole pressure profiles for the vapor-dominated reservoirs around the world (JICA 1992; Allis and Shook 1999; Layman and Soemarinda 2003; Bogie et al. 2008). Volcano-hosted reservoirs (colored continuous lines); plutonic-hosted vapor-dominated reservoirs (dashed lines). Las Pailas liquid-dominated reservoir, and lithostatic and hydrostatic profiles were included as a reference

in an extensional retro-arc environment associated with a post-collisional stage (Batini et al. 2003). Both are plutonic-hosted reservoirs and are related to an entirely different tectonic setting from the Copahue volcano. On the other hand, West Java, Indonesia, has the only natural volcano-hosted vapor-dominated reservoirs currently known (i.e., Patuha, Kamojang, Darajat, Telagabodas, and Wayang Windu; Bogie et al. 2015). The volcano-tectonic setting at Java is subjected to a rapid trench roll back that controls the stress field of the extensional volcanic arc (Katili 1975; Schlüter et al. 2002). Numerical models showed that the factors contributing to the occurrence of the vapor-dominated reservoirs in West Java are strong heating due to prolonged active volcanism, the absence of shear faulting, and a restrictive range of permeability distribution (Raharjo et al. 2016).

It is interesting to note that all the volcano-hosted vapor-dominated reservoirs show the same three-segment pattern in the pressure vs. depth curve. The shallow segment has a high-pressure gradient in response to a hydrostatic column. The intermediate segment shows a slow pressure gradient indicating two-phase or single vapor-phase conditions. The bottom segment has a hydrostatic pattern that highlights the presence of the deeper liquid-dominated reservoir.

The temperature profiles in the wells of Copahue have a typical linear trend that converges at $800-1000 \mathrm{~m}$ depth to an isothermal profile, thus suggesting an upper thermal cap and a deep convective zone (Fig. 3). The latter could be attributed to a 


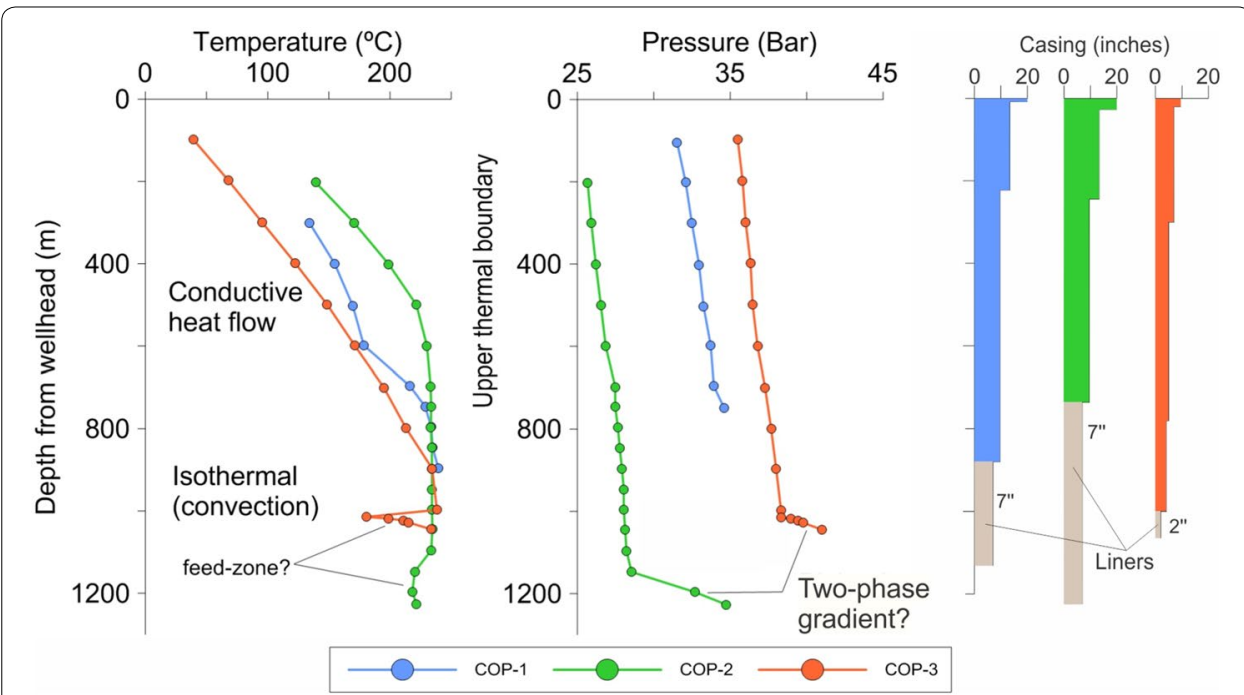

Fig. 3 Temperature and pressure profiles at no-flow condition from the wells of Copahue (see well locations in Fig. 1; JCA 1992). The casing-liner distribution for each well is also shown

stratigraphic control over the permeability. The static pressure profiles (Fig. 3) suggest a similar interpretation. The slight pressure increase observed below $1000 \mathrm{~m}$ depth, with lower than the hydrostatic pressure values, could respond to the active control of a boiling fluid over the column of the wells. Therefore, the pressure vs. depth curve at Copahue shows significative differences from those identified in the volcano-hosted vapor-dominated reservoirs, as was shown above, except in the case of Darajat. The latter has a straight segment of very low-pressure gradient, in good agreement with the first km depth of Copahue (Fig. 2). Numerical simulations predict a liquid-dominated deep reservoir below $3 \mathrm{~km}$ depth at Darajat (Alamsyah et al. 2005). However, the same conditions cannot be inferred for Copahue given the shallow depths reached by those wells.

It is interesting to highlight that the very low-pressure gradient found along the shallow section of Copahue wells is a rare feature. Several numerical simulations performed by Pratama and Saptadji (2016) based on a two-phase liquid-dominated geothermal reservoir with a steam cap underlying brine reservoir model permits a sound interpretation. Such models reveal that pressure in boiling zones increases slightly until the main deep reservoir level, where the gradient turns to hydrostatic conditions, like a conventional liquid-dominated reservoir. In addition, the pressure profile differs from the center to the edge of the models. These differences should be taken into account to interpret the pressure profiles at the Copahue reservoir correctly.

Copahue wells show a dramatic pressure gradient increase from $900 \mathrm{~m}$ downward, adopting an almost hydrostatic behavior (Fig. 3). There are several explanations for this response, including a feed zone, condensation of steam, and accumulation in a dead leg or an artifact by the configuration of the casing and perforated liner. Another explanation might be the existence of a water level near the well bottom. In any case, if this trend is confirmed, the pressure profile would agree with a shallow vapor zone underlying a deeper two-phase reservoir. 
The rare occurrence of vapor-dominated reservoirs contrasts with the frequent presence of steam caps or vapor zones above liquid-dominated reservoirs (Raharjo et al. 2016). Moreover, the formation of the steam caps is common in volcano-hosted liquid-domain reservoirs. Good examples of these local vapor zones at volcanohosted systems are found at Ahuachapan in El Salvador (Monterrosa and López 2010), Monte Aso in Japan (Shibuya et al. 2000; Terada and Sudo 2012), or Tolhuaca in the compressive volcanic arc of Chile (Melosh et al. 2012; Iriarte 2013), among others. All these cases are probably related to deep feed zones that subject the reservoir to a local increase of permeability and heat flux. In exceptional cases, such as of the $\mathrm{Te}$ Mihi at the Wairakei geothermal system, the production forces a pressure drop and led to the formation of a significantly productive vapor zone from a liquid-dominated reservoir (Thain and Carey 2009). In addition, the development of vapor zones could be overlaid by shallow steam-heated waters, so a sealed upper boundary may not be essential (Ingebritsen and Sorey 1988; Hochstein and Sudarman 2000). This setting is consistent with the isotopic signature of the fumaroles at the western margin of the Copahue reservoir given the interaction inferred between deep geothermal fluids and the shallow steam-heated water table (Chiodini et al. 2015; Roulleau et al. 2016).

\section{Surface geothermal manifestations: the high-sulfidation system}

The development of a vapor-dominated reservoir is commonly related to a pressure drop over a deep liquid-dominated reservoir and responds to a couple of input-output constraints. The first one is that the recharge must be slow enough to boil. Otherwise, the vapor zone would be flooded with liquid (Raharjo 2012). The second one is the existence of surface leaks that allow the steam cap growth with time (White et al. 1971). If not, the system would pressurize, slowing or stopping evaporation from the underlying boiling brine. Hydrothermally altered soils, fumaroles, and hot springs are evidences of these fluid leaks. Therefore, they can be used to infer the physicochemical conditions at depth.

A total of five active hydrothermal zones altered by steam-heated fumarolic activity characterize the main geothermal manifestation of Copahue (Fig. 4). The fumaroles are near boiling temperature at the altitude of the gas emissions, with more than $97 \%$ of vapor phase (JICA 1992; Agusto et al. 2013; Tassi et al. 2017). The dry gas phase is predominantly composed by $\mathrm{CO}_{2}$, with significant concentrations of $\mathrm{H}_{2} \mathrm{~S}$ and very low concentrations of the acid species. All the hot springs are acid sulfate, because the interaction between a water table and the oxidation of $\mathrm{H}_{2} \mathrm{~S}$ was carried by the fumaroles (JICA 1992, Agusto et al. 2012b; Gaviria Reyes et al. 2016). It is interesting to note the lack of travertine deposits and that only one siliceous sinter was recognized at an inactive surficial manifestation (Mas et al. 1996). Acid springs usually develop by high sulfidation related to a vapor-dominated system (Ingebritsen and Sorey 1988). Moreover, it has commonly been assumed that the absence of both near-neutral-pH alkali-chloride hot springs and siliceous sinter deposits is consistent with a vapor-dominated reservoir (White et al. 1971).

Mas et al. (1996) studied the altered soils at local depressions originated by strong pervasive alteration of the country rock. There are composed of alunite-kaolinite bearing assemblage with subordinated cristobalite, quartz, and cryptocrystalline jarosite, depending on the alteration degree (Fig. 4; Mas et al. 1996). This type of hydrothermal 


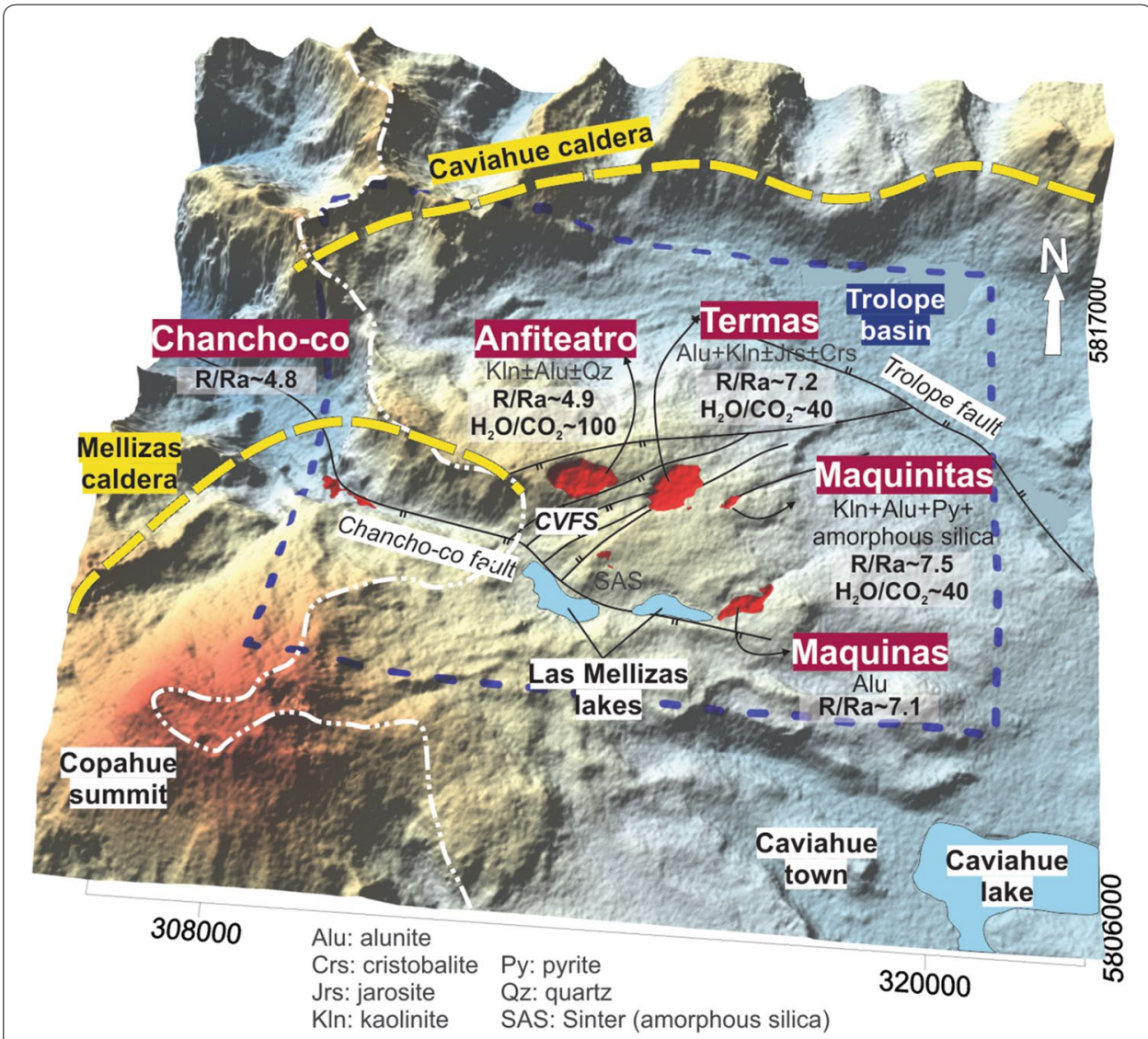

Fig. 4 Chemical features of the geothermal manifestations (red patches) at Copahue geothermal field overlying a 3D view of the topography (blue-red colormap; Shuttle Radar Topography Mission data). Chemical and isotopic data from Chiodini et al. (2015) and Roulleau et al. (2016). Hydrothermal soil composition from Mas et al. (1996)

alteration currently develops at vents of active volcanoes where magmatic gases as $\mathrm{SO}_{2}$ and $\mathrm{HCl}$ occur at high concentrations (White and Hedenquist 1995). Therefore, aluminous-rich hydrothermal alteration assemblage related to the Copahue surficial manifestations is also of high-sulfidation type. Numerous works have demonstrated the existing relationship between sulfidation degree of epithermal systems and geothermal reservoirs (e.g., Henley and Ellis 1983; Henley et al. 1986; Hedenquist et al. 1992; Corbett and Leach 1993). While liquid-dominated reservoirs are related to low sulfidation assemblage, vapor-dominated ones are related to high-sulfidation assemblage. Unfortunately, the surface hydrothermal manifestations are not conclusive given that liquid-dominated reservoirs can develop high-sulfidation alteration, including alunite-kaolinite bearing soils, when related to shallow steam zones (e.g., González-Partida et al. 2005).

Several geothermal systems at a wide range of tectonic settings have a shallow steamheated boiling aquifer overlying a pressurized liquid reservoir (e.g., Palinpinon at Philippines, Los Azufres at Mexico or Olkaria at Kenia; Grant and Bixley 2011), and the volcanic-hosted reservoir is not the exception (Tiwi at Philippines or Matsukawa at Japan; Gambill and Beraquit 1993; Hanano and Matsuo 1990). These steam-heated acid sulfate springs usually develop the advanced argillic assemblages composed by 
opal + alunite + kaolinite + pyrite (Pirajno 2009), as the alteration showed by the soils of Copahue (Fig. 4). Therefore, hydrothermal alteration above a vapor-dominated geothermal reservoir is similar to that found in local shallow, steam-heated zones above a boiling liquid-dominated reservoir (Boden 2016).

The X-ray diffraction profile from Cop-3 well (JICA 1992) provides several complementary information (Fig. 5). What is striking in Fig. 5 is the presence of kaolinite + smectite +-illite-chlorite-pyrite until $700 \mathrm{~m}$ depth, where the presence of kaolinite indicates that the shallow host rock is or was subjected to a pervasive steam-heated alteration. On the other hand, the assemblage epidote + chlorite + Illite + smectite + wairakite domains below the $800 \mathrm{~m}$ depth. The latter mineral assemblage is characteristic of high temperature (over $225^{\circ} \mathrm{C}$ ) at neutral-to-alkaline environments (Elder and Moore 2016 and references therein). Therefore, the mineral assemblages recognized in the Copahue wells allow defining a shallow argillic and a deep propylitic alteration zone, according to the hydrothermal alteration terminology reviewed by Gifkins et al. (2005). The development of shallow acid and deep neutral environments might be a consequence of the leak at productive and nonproductive

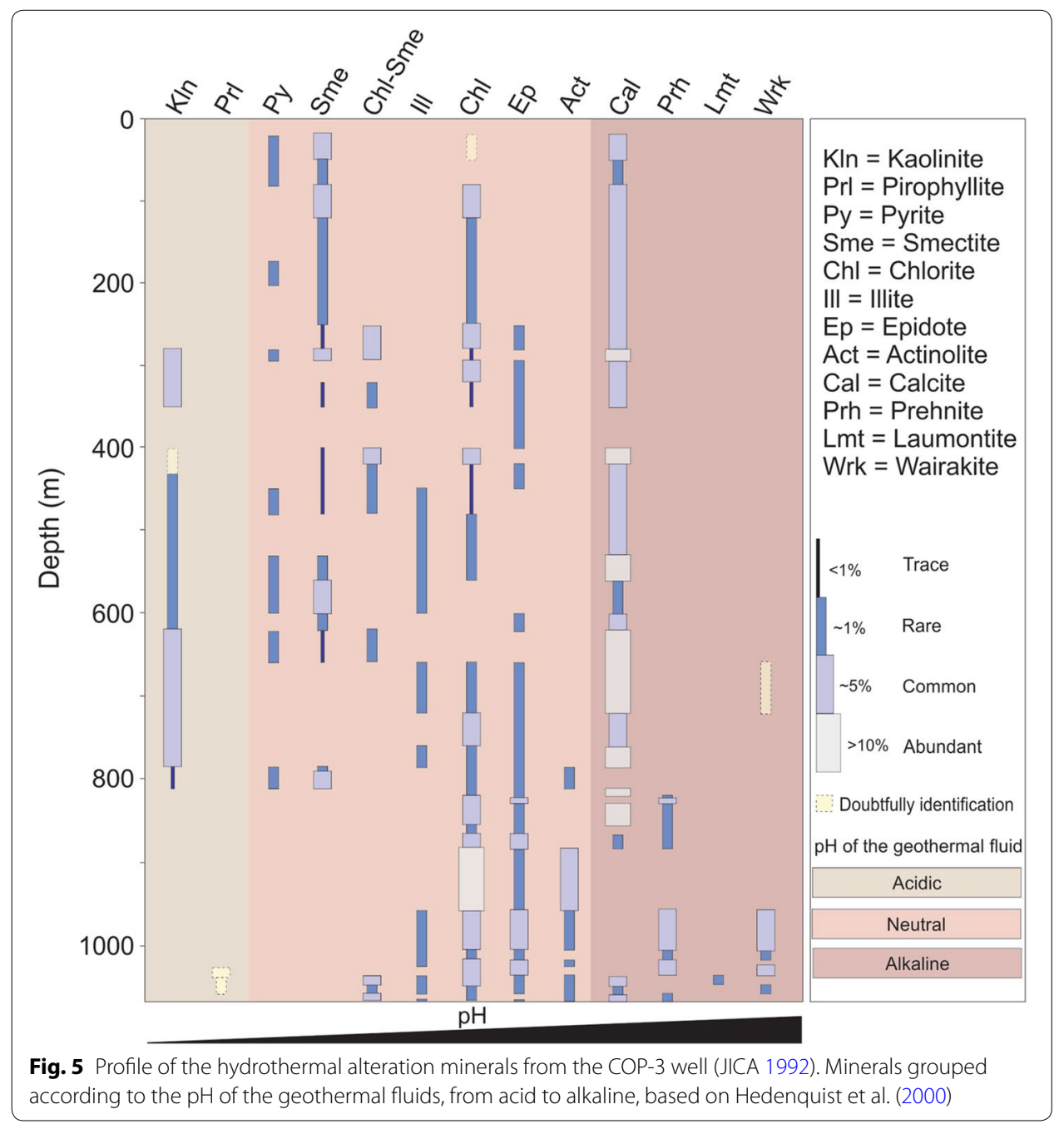




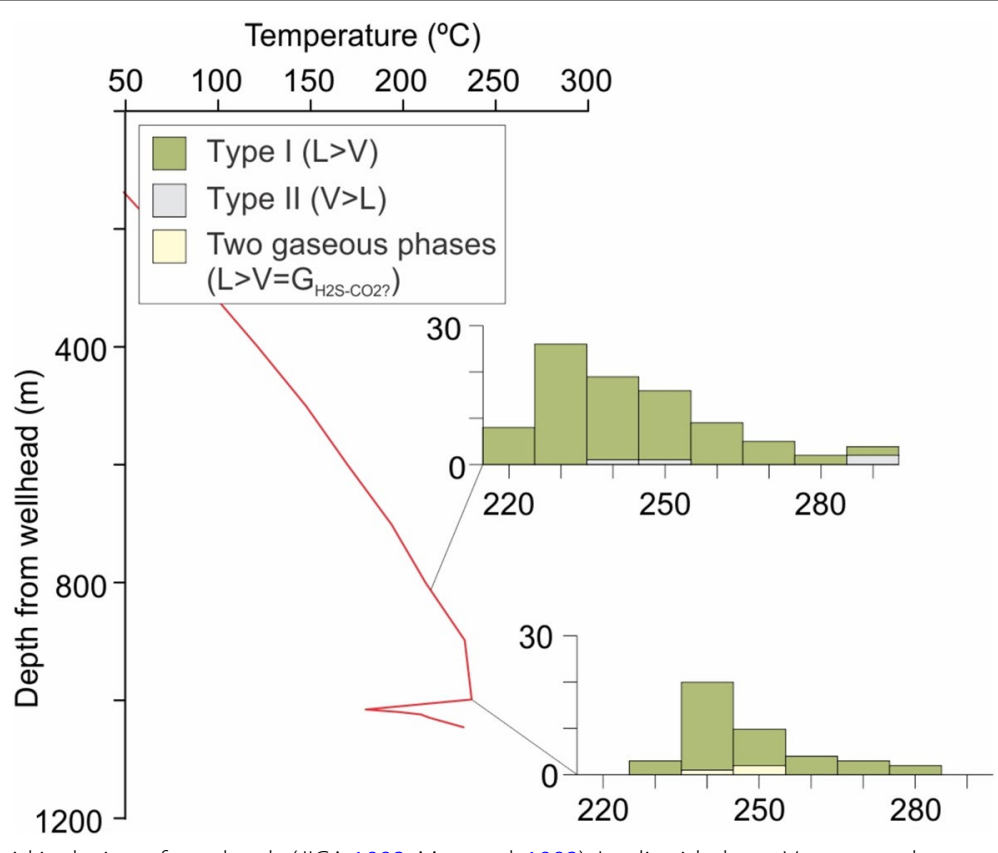

Fig. 6 Fluid inclusion of two levels (JICA 1992; Mas et al. 1993). L= liquid phase; $V=$ vapor phase; $\mathrm{G}=$ uncondensable phase

steam zones or steam caps. For example, the productive Darajat vapor-dominated reservoir shows a clay cap composed by illite-smectite mixed layer until $1 \mathrm{~km}$ depth, followed by a propylitic alteration with chlorite, pyrite, epidote, and illite at the reservoir (Rejeki et al. 2005, 2010). In the case of Copahue, the alteration zone distribution does not differ from the other liquid-dominated geothermal systems with a shallow vapor zone developed at similar latitudes along the Andean volcanic arc (e.g., the Tolhuaca geothermal system; Melosh et al. 2010; Sanchez-Alfaro et al. 2016). Thus, caution must be taken regarding the interpretation of surface and subsurface alteration. We cannot discern between liquid-dominated and vapor-dominated reservoirs, but it is, nevertheless, possible to infer a shallow vapor zone above a deeper two-phase reservoir.

A thorough analysis of the alteration mineralogy shown in Fig. 5 reveals a complex hydrothermal alteration history. The coexistence of chloride with smectite, chloridesmectite, and Ca-zeolites may be explained by the over imposition of more than one hydrothermal alteration event. The lack of textural characteristics of the mineralogical assemblage obscures the thermal-alteration path. Unfortunately, no textural analysis is available, so it is impossible to clarify the thermal-alteration path. However, hand specimen studies, petrography, and the X-ray diffraction observations allowed. Mas et al. (1995) to define three partially overlapped Ca-zeolites zonations, consistent with changes in the thermal structure of the reservoir.

JICA (1992) and Mas et al. (1993) report a fluid inclusion (FI) study based on six cutting and core samples of the Cop-3 borehole below $800 \mathrm{~m}$ depth. Based on these data, they propose a thermal evolution for the reservoir, which helps to understand in turn its physicochemical conditions. Type I fluid inclusions (i.e., the liquid is the dominant phase) have a homogenization temperature of $230^{\circ}$ and $240{ }^{\circ} \mathrm{C}$ for $800 \mathrm{~m}$ and $1000 \mathrm{~m}$ 
depth, respectively, whereas the static temperature indicates $210{ }^{\circ} \mathrm{C}$ and $240{ }^{\circ} \mathrm{C}$ at the same two depths (Fig. 6). This analysis suggests a good agreement between the current thermal state and the one recorded with FI. However, the $\Delta \mathrm{T}$ of $-20{ }^{\circ} \mathrm{C}$ at $800 \mathrm{~m}$ depth points out a slight thermal structure depression that could be explained by an improved transmissivity compared to the FI formation times. Some FI found at $800 \mathrm{~m}$ depth samples were identified as Type II (i.e., vapor is the dominant phase), suggesting that they were formed at boiling conditions. Nevertheless, the homogenization temperature was not correctly defined (between 250 and $300{ }^{\circ} \mathrm{C}$ ) because of the low number of FI analyzed (only four, see Fig. 6). A preliminary interpretation of this data set shows that the current boiling depth (around $800 \mathrm{~m}$ ) had a higher temperature than the present (Mas et al. 1993). The presence of laumontite and wairakite at the borehole bottom provides a complementary approach: if we consider that they are forming a paragenesis, a potential equilibrium temperature could be determined. The pressure at $1000 \mathrm{~m}$ depth is around 2.7-2.8 kb, resulting in a laumontite-wairakite equilibrium temperature of about $220^{\circ} \mathrm{C}$ (Liou 1971; Kiseleva et al. 1996). Static temperature is $240^{\circ} \mathrm{C}$ at the bottom of the borehole, so the current thermal structure is increased by about $\Delta T=25^{\circ} \mathrm{C}$. Probable explanations for the latter $\Delta \mathrm{T}$ would be variations in the heat source (e.g., magma injection at the volcano chamber), a shallower fragile-ductile transition that would hamper heat conduction to the surface, or the inflation-deflation dynamic process. The estimated temperature based on the laumontite-wairakite equilibrium approach differs from the temperature recorded by the FI at the bottom borehole, so new multiproxy studies are needed to understand the thermal evolution of the system.

There is an approximate correspondence between the area of the geothermal field, the surficial heat flux, and the type of geothermal system. In the Larderello geothermal system, for example, the heat flow is about $\sim 0.5 \mathrm{MWkm}^{-2}$ over more than $70 \mathrm{~km}^{2}$ (Bellani et al. 2004, Della Vedova et al. 2008). On the other hand, values from $4 \mathrm{MWkm}^{-2}$ until $12 \mathrm{MWkm}^{-2}$ over more than $15 \mathrm{~km}^{2}$ are needed to explain the current state of the vapor-dominated systems of Kamojang and Darajat (Raharjo 2012, Raharjo et al. 2016). Allis (2000) analyzed the thermal regime over both intrusion-hosted and volcano-hosted vapor-dominated systems. He concluded that while the former is characterized by 1

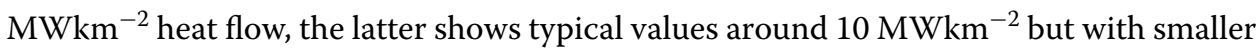
reservoir areas $\left(\sim 10 \mathrm{~km}^{2}\right)$. These features partially contrast with the proposed heat flow for Copahue. A surface heat flow of $0.3 \mathrm{MW} \mathrm{km}^{-2}$ over an area of $20 \mathrm{~km}^{2}$ was calculated based on gradient well measures reported by Mas et al. (2000). Although these values reflect a relatively large heat source, they are still lower than previously described for entirely volcano-hosted vapor-dominated systems.

\section{Redox condition of the geothermal reservoir by fluid geochemistry}

It is known that fumaroles and fluids from wells play an essential role in the study of the physicochemical conditions of deep reservoirs. That is because of the equilibrium reaction velocities involved in the fluids' host-rock system (Nicholson 1993; Arnórsson 2000). In contrast to high-velocity reactions, low-velocity reactions imply a lower chance of chemical re-equilibration at shallower levels during the upwelling of the geothermal fluids. Therefore, it is possible to infer different processes and physicochemical 

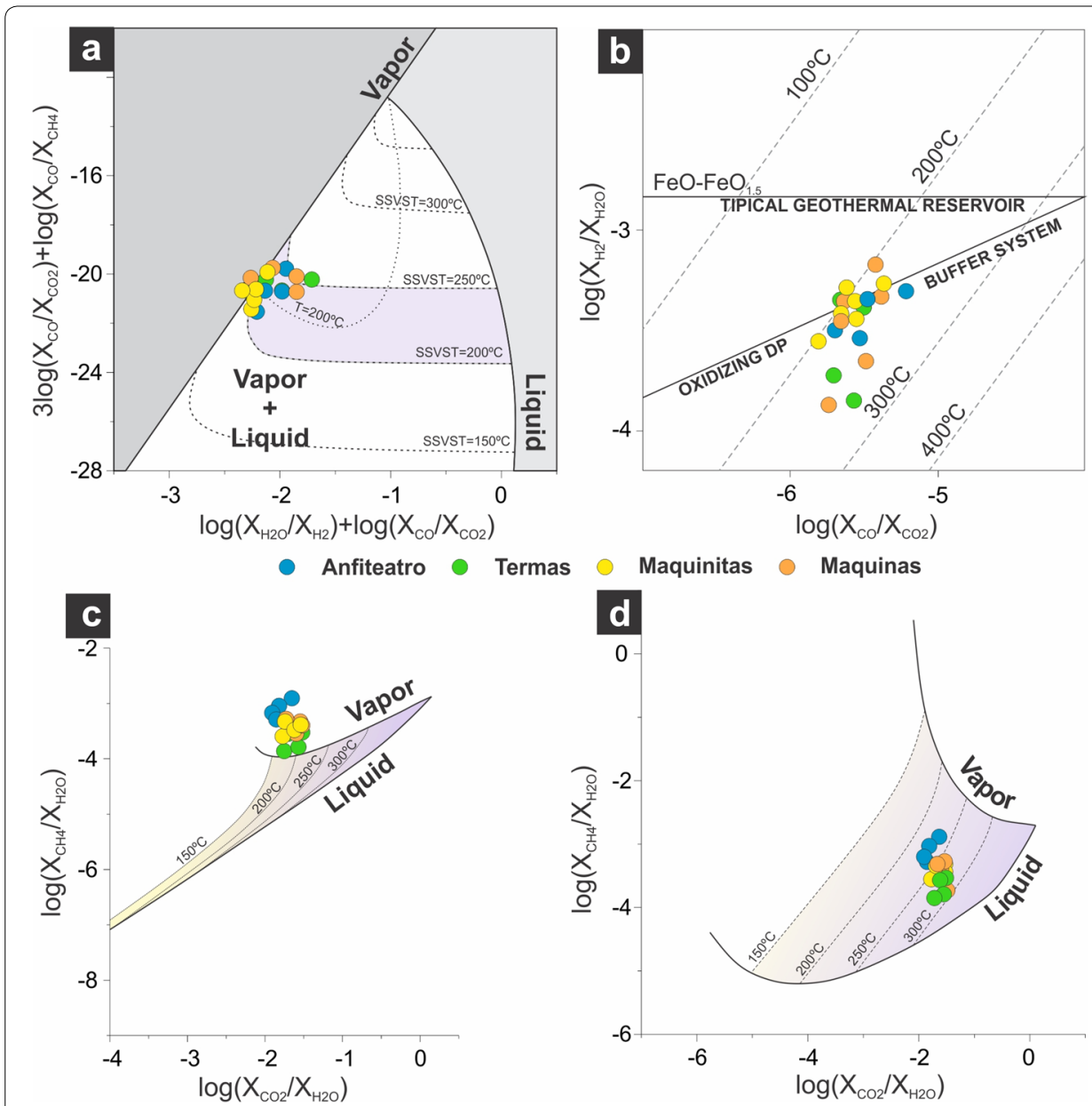

Fig. 7 Chemical fluid approach to infer the physicochemical features of the geothermal reservoir in Copahue, according to Agusto et al. (2013). Gas discharge composition database from Jurío (1977), Panarello (2002), Martini et al. (1997), Agusto et al. (2013), and Tardani et al. (2016). a Binary diagram for the $\mathrm{CO}-\mathrm{CO}_{2}-$ $\mathrm{H}_{2}-\mathrm{H}_{2} \mathrm{O}$ system. Theoretical single-saturated vapor phase and single-saturated liquid phase are shown. $\mathbf{b}$ $\log \left(\mathrm{XH}_{2} / \mathrm{XH}_{2} \mathrm{O}\right)$ vs. $\log \left(\mathrm{XCO} / \mathrm{XCO}_{2}\right)$ binary diagram with theoretical compositions of the vapor in equilibrium controlled by the DP redox buffer (D'amore and Panichi 1980) and the typical FeO-FeO ${ }_{15}$ geothermal buffer reaction (Giggenbach 1987). $\mathbf{c} \log \left(\mathrm{XCH}_{4} / \mathrm{CH}_{2} \mathrm{O}\right)$ vs. $\log \left(\mathrm{XCO}_{2} / \mathrm{XH}_{2} \mathrm{O}\right)$ binary diagram; vapor and liquid phase fields controlled by DP redox buffer are also shown (D'amore and Panichi 1980). $\mathbf{d} \log \left(\mathrm{XCH}_{4} / \mathrm{CH}_{2} \mathrm{O}\right)$ vs. $\log \left(\mathrm{XCO}_{2} / \mathrm{XH}_{2} \mathrm{O}\right)$ binary diagram; theoretical compositions of equilibrated vapor and liquid phases at redox conditions controlled by the $\mathrm{FeO}-\mathrm{FeO}_{1.5}$ redox buffer are shown

characteristics at a wide range of depth levels by studying the developed chemical systems with their respective reactions velocities.

For example, the $\mathrm{H}_{2}-\mathrm{CO}_{2}-\mathrm{CH}_{4}-\mathrm{CO}-\mathrm{H}_{2}$ system proposed by Chiodini and Marini (1998) would allow estimating the reservoir temperature, assuming the oxidizing conditions in the reservoir. For this system, the fluids of Copahue are partially equilibrated at the single vapor phase (Fig. 7a). However, the estimated temperature, around $225^{\circ} \mathrm{C}$, is significantly lower than the direct measure of $\sim 255^{\circ} \mathrm{C}$ at the bottom of the well (JICA, 1992). This difference was attributed to shallow re-equilibration processes (Agusto et al. 2013) triggered by the high-velocity reaction of the $\mathrm{CO}$ and $\mathrm{H}_{2}$ in the system (Giggenbach 1987; Chiodini et al. 1993; Giggenbach 1997; Chiodini et al. 2002). Besides, the $\mathrm{FeO}-\mathrm{FeO}_{1.5}$ redox buffer reaction chemically controls the typical hydrothermal 
reservoirs (Giggenbach 1987). Figure $7 \mathrm{~b}$ shows that the fluids from Copahue are not in equilibrium with a single-phase vapor at an oxidized reservoir medium. Therefore, the partial single-vapor-phase equilibration would not represent the deep conditions where the reservoir hosts.

Agusto et al. (2013) have previously studied the deep processes using the $\mathrm{CO}_{2}-\mathrm{CH}_{4}$ bearing system, which is less susceptible to re-equilibrate at shallow depths (Giggenbach 1991). These authors found that overheated fluids at Copahue dominate the vapor-single phase when they are analyzed regarding the DP buffer system (Fig. 7c). This overheated state suggests that the system is not in equilibrium and that more reducing conditions are needed to explain the chemical data. However, Fig. $7 \mathrm{~d}$ reveals that the Copahue geothermal fluids tend towards equilibrium in the liquid phase field at a temperature range of $250-290^{\circ} \mathrm{C}$ (Agusto et al. 2013), regarding neutral or slight reductive conditions with the $\mathrm{FeO}-\mathrm{FeO}_{1.5}$ pair as the dominant redox buffer system. The estimated temperature range is consistent with the direct measures available (see Fig. 3) and corresponds to a near-neutral pH liquid-dominated reservoir.

The existence of slight reducing to neutral conditions in the reservoir is in agreement with the alteration mineralogy identified at the bottom wells (Fig. 5). Besides, a zonation of stilbite, laumontite, and wairakite was identified, and the existence of Ca-bearing zeolites supports both slightly alkaline conditions and the fact that $\mathrm{XCO}_{2}$ is low enough to stabilize $\mathrm{Ca}-\mathrm{Al}$ silicates (Mas et al. 1995). This mineral alteration assemblage differs from the vapor-dominated or steam-heated alteration above a boiling liquid-dominated reservoir because of the highly acid alteration assemblage of the host rock (Boden 2016).

A complementary approach is supported by elementary abundances of noble gases that are fingerprints of physical changes in the geothermal reservoir (Ozima and Podosek, 2002; Pinti et al. 2013). Roulleau et al. (2016) analyzed noble gases and stable isotopes of several geothermal fluid samples of Copahue and showed that the R/Ra values are constant with the increase of normalized ${ }^{132} \mathrm{Xe}$ (Fig. 8). These authors concluded

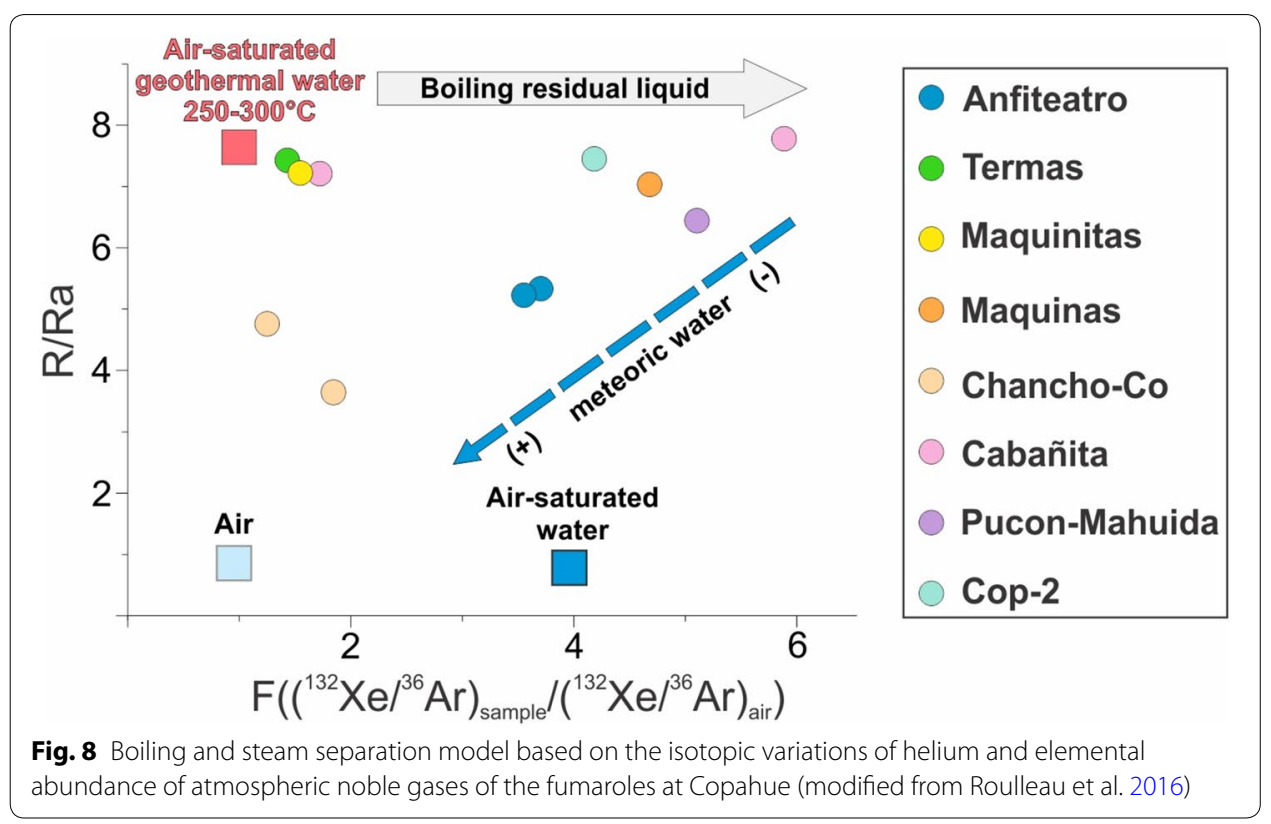


that (a) strong elemental fractionation due to boiling and the steam separation of a deep liquid-dominated reservoir at temperatures between 250 and $300{ }^{\circ} \mathrm{C}$ modified the original composition and (b) increasing participation of the meteoric water during the boiling, and a steam separation at shallow levels at marginal fumaroles are both occurring. The latter suggests that the steam cap has variable thickness and that the thicker zones correspond to Termas de Copahue, Máquinas, and Maquinitas geothermal zones. This hypothesis is in agreement with the chemistry of the fumaroles at the western border of the reservoir (see Fig. 4) and with the vapor zone defined by diffuse $\mathrm{CO}_{2}$ gas by Chiodini et al. (2015).

\section{Well-production data and the vapor zone}

The deep-drilling exploration stage at Copahue was carried out during several on and off stages between 1976 and 1991, and leads to perform production tests over a total of three exploratory wells. The static column of steam with only vapor-phase discharge is the main characteristic of the vapor-dominated reservoirs. After the exploratory wells at Copahue were opened, the main discharge was dry steam, and the results led to Nakanishi et al. (1995) to propose the vapor-dominated nature of this geothermal system. Although the unpublished feasibility report performed by JICA (1992) is consistent with this assumption, an additional information should be considered.

Sierra et al. (1992) reported the production data from the first two drilled wells (i.e., COP-1 and COP-2; Fig. 9a). The most exciting aspect of the data is that the initial dry vapor production declined and the further production turned into a two-phase discharge until the exhaustion of the feed zone. The authors applied the $\mathrm{H}_{2}-\mathrm{CH}_{4}-\mathrm{CO}_{2}-\mathrm{H}_{2} \mathrm{O}$ system proposed by D'amore and Truesdell (1985) to calculate not only the temperature of the reservoir but also the vapor fraction. Figure $9 \mathrm{~b}$ reveals that there has been a marked drop in the molar steam fraction during the production test over the three wells, suggesting the exhaustion of the feed zone or the existence of a deeper liquid-dominated reservoir.

The isotopic composition of the fluids during the production test was tracked at both wells to understand the fluid source and its relation with the host rock. Panarello (2002) identified the depletion of $\delta^{18} \mathrm{O}$ and inferred that the shallow feed zone has a low permeability connection with the deeper liquid-dominated reservoir, suggesting that there is no lateral recharge. Both the fluid discharge and the isotopic evolution indicate the existence of an isolated shallow steam cap, at least located around the vicinity of the drilled wells (i.e., Las Mellizas Lake). A third exploration well was subjected to a short production test for only 16 days. Despite no discharge depletion having been identified, JICA (1992) pointed out that the steam discharge was not a consequence of extensive flow testing and suggested the possibility that similar behavior should be expected if the tests continued over time. The data reviewed so far indicate a) the existence of a nonproductive shallow steam cap, and $b$ ) that the main reservoir could not have been reached by the wells.

\section{The layered model of the Copahue geothermal reservoir}

The pressure-temperature-depth profiles, chemical and isotopic nature of the fluids discharge, hydrothermal alteration assemblage, and production test data are independent evidence that converges into a general reservoir model. We propose that the 

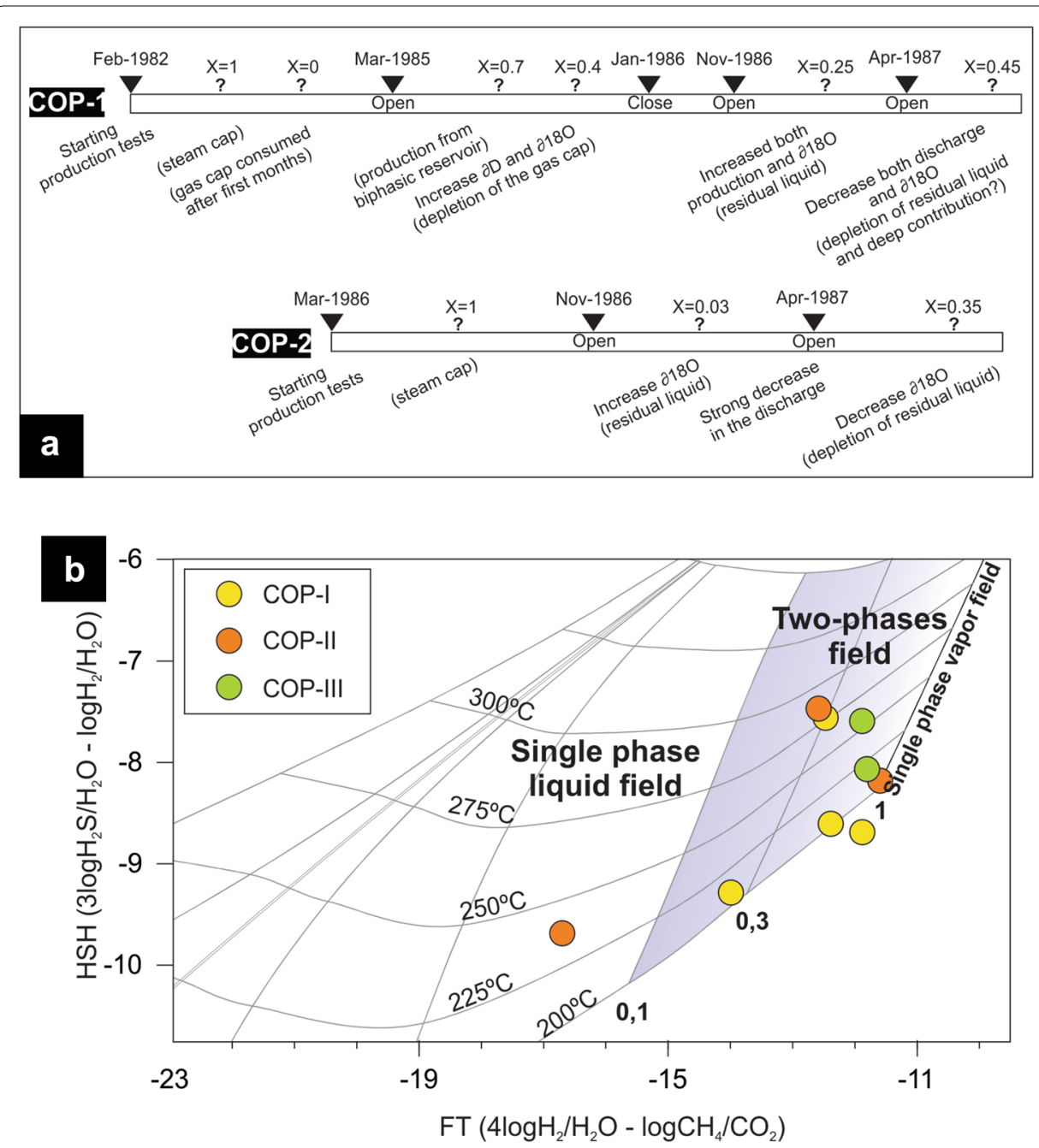

Fig. 9 Available production data from the exploratory wells at Copahue. a Timeline of the production data from Sierra et al. (1992) for two wells. The interpretation based on water isotopes is shown in brackets. X = steam molar fraction. b FT-HSH diagram (D'Amore and Truesdell 1985) from fluid discharge during different stages of production tests that shows a variable vapor-liquid fraction (Panarello 2002)

Copahue geothermal system is driven by the dynamics of a stratified reservoir composed of a steam-heated vapor zone above a liquid-dominated reservoir (Fig. 10). This model explains the acid sulfate fluids, the absence of both siliceous sinter and chloride-alkaline hot springs and the aluminous-rich clays as part of the high-sulfidation assemblage at the surface, the pressure-depth profiles, the chemical re-equilibrations observed by different systems, the reduced-to-neutral $\mathrm{pH}$ condition, and the propylitic phase at depth.

As shown in Fig. 10, the conductive temperature vs. depth profile develops an upper thermal boundary, which corresponds with the Las Mellizas Formation. A constitutive part of this layer is the clay cap, composed of smectite + chlorite + illite + kaolinite alteration mineral assemblage. The clay cap is characterized by both a resistivity structure of $\sim 10 \Omega . \mathrm{m}$ and a very low magnitude and density of the seismic events (JICA 1992; Lazo et al. 2015; Lundgren et al. 2017), and is part of the stilbite zeolite zone of Mas et al. (1995). The existence of this low permeability layer correlates with the identified 


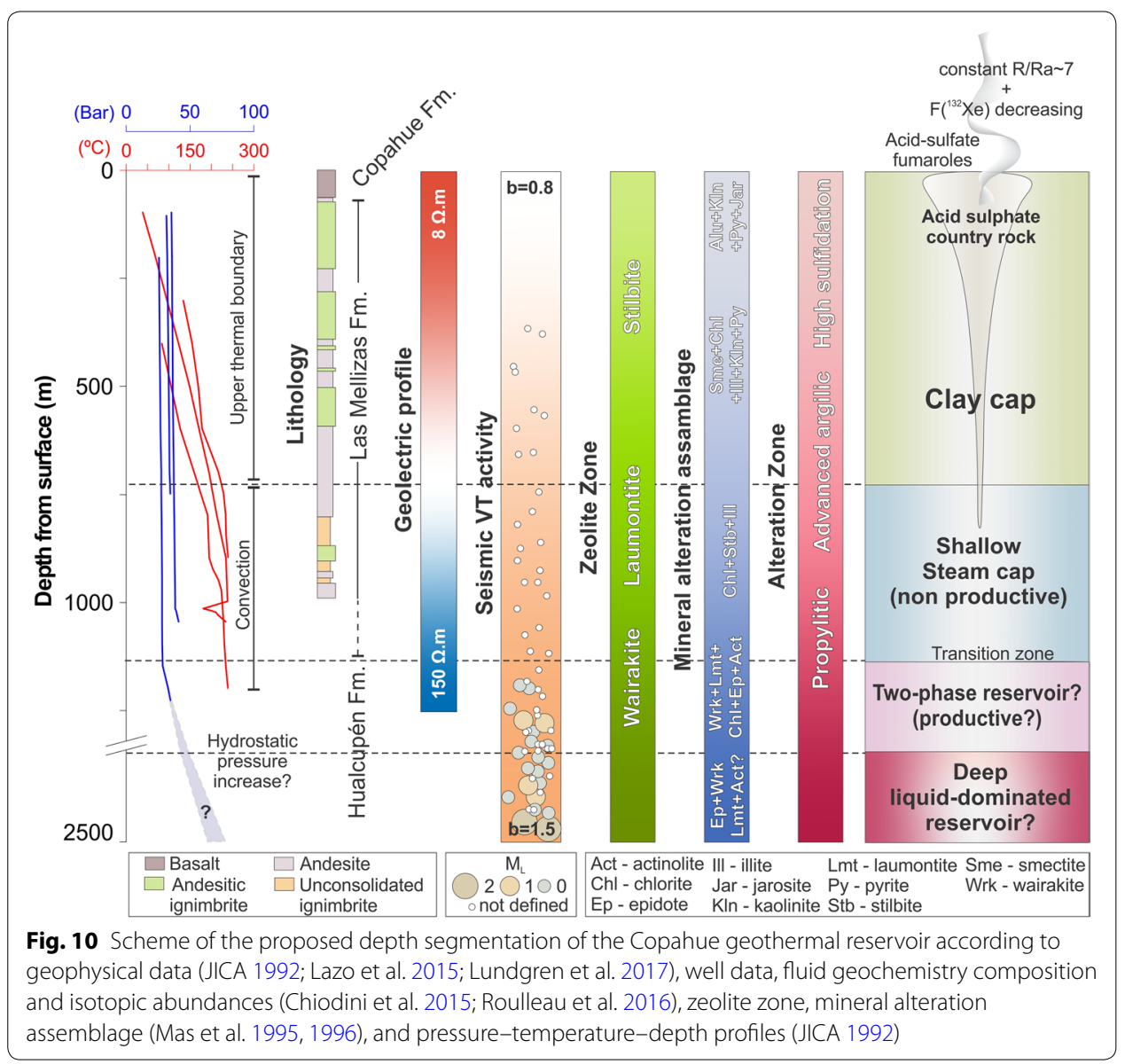

acid argillic alteration zone. Temperature profiles indicate that the bottom of the thermal boundary is placed at $800 \mathrm{~m}$ depth, highlighting the efficiency of the well-developed clay cap (Fig. 10). Despite the relevance of the magnetotelluric surveys to define the clay cap extension and thickness (Gunderson et al. 2000; Cumming and Mackie 2007; Heise et al. 2008), the available data from Mamani et al. (2000) and Borzotta et al. (2018) were ruled out because of the low quality of the signal and the inadequate distance between the measured stations.

Immediately below the clay cap, there is a shallow steam cap that is identified in the well $\log$ by the isothermal segment (Sierra et al. 1992; Nakanishi et al. 1995). This vapor zone is hosted in the bottom of Las Mellizas Formation, showing poor seismic activity and low electric conductivity response $(\sim 120 \Omega . \mathrm{m})$, in agreement with the lack of smectite (see the temperature profile and both the geoelectric and mineral alteration column in Fig. 10). Gas geothermometers based on the high-velocity reequilibration system indicate a temperature of $200-215{ }^{\circ} \mathrm{C}$ for this shallow vapor reservoir, consistent with direct borehole measurements (JICA 1992; Agusto et al. 2013; Chiodini et al. 2015). The production data reported by Sierra et al. (1992) and isotopic abundances analysis performed by Panarello (2002) are in good agreement with an isolated and nonproductive zone, at least around the volume influenced by the wells. In addition, the presence of kaolinite at the top of this shallow steam cap suggests 
that it was formed by the interaction between the boiling zone and the host rock. A feasible explanation for the development of this shallow steam cap might be that a high permeability zone would have promoted a depressurization of the thermal fluids. Production data suggest that the feed zone reached by the exploration wells is the top of the shallow steam cap (Panarello 2002).

The physicochemical condition of a deep reservoir below the steam cap is the main discussion point. Despite some slight contradictions between the report of JICA (1992), Sierra et al. (1992), and Panarello (2002), our fluid chemical analysis approach ("Redox condition of the geothermal reservoir by fluid geochemistry" section) suggests the presence of a two-phase reservoir at depth. Recalibration of the $\mathrm{CO}_{2}-\mathrm{CH}_{4}$ bearing system at neutral-to-alkali reservoir conditions showed that the fluids are not equilibrated at vapor-saturated conditions (Agusto et al. 2013). It is possible, therefore, that a liquid phase might dominate the geothermal reservoir at Copahue. The boiling and steam separation model that explains the Xe increase and the constant $\mathrm{R} / \mathrm{Ra}$ at the fumaroles (Roulleau et al. 2016) reinforces that hypothesis. The exploratory wells reached the base of the clay cap and likely hit near the top of this reservoir, located at 1100-1200 m depth (Fig. 10). Although biased measurements should not be ruled out, rapid pressure gradient rise at the bottom of the profiles might be responding to a hydrostatic column, thus suggesting a two-phase, transitional zone fed by the deeper reservoir. This zone correlates with an increase in the recorded seismic activity related to fluid pore pressure rise, and with the presence of wairakite, laumontite, and epidote as main alteration minerals (see seismic volcano-tectonic activity and mineral alteration assemblage columns in Fig. 10).

We propose that a liquid-dominated system composes the lower part of this system, probably below $1500 \mathrm{~m}$ depth. The more reliable gas geothermometer $\left(\log \left(\mathrm{XCH}_{4} / \mathrm{CH}_{2} \mathrm{O}\right)\right.$ vs. $\log \left(\mathrm{XCO}_{2} / \mathrm{XH}_{2} \mathrm{O}\right)$; Agusto et al. 2013) indicates a temperature of $270-280{ }^{\circ} \mathrm{C}$ and near-neutral $\mathrm{pH}$ conditions. Homogenization temperatures of fluid inclusions found in quartz from cutting samples (Mas et al. 1993) are consistent with the gas geothermometers. A pervasive propylitic alteration affects the Cola de Zorro-Hualcupén Formation that host the reservoir. The likely mineral assemblage is wairakite + laumontite + chlorite + epidote + prehnite + actinolite. Coexistence of wairakite and actinolite suggests good permeability and temperature up to $280{ }^{\circ} \mathrm{C}$. This mineral assemblage is partially recognized in the COP-3 well (see Fig. 5).

Since no direct measurements were taken, the thickness of the liquid-dominated reservoir will remain under debate; however, seismic activity registered at the volcanohydrothermal system provides some clues. The first hypocenter distribution of the volcano-tectonic earthquakes at Copahue was presented by Lazo et al. (2015), based on the collected database from OVDAS. A curious aspect of the data is a seismic gap at $3 \mathrm{~km}$ depth that could be constraining the bottom of the reservoir. The main problem is the large vertical error bars $(0.6 \mathrm{~km})$ of the hypocenter locations. Velez et al. (2011), in turn, proposed a carapace zone (i.e., a strong permeability reduction below a shearductile zone) at $2 \mathrm{~km}$ depth as the bottom of the deep reservoir. Nevertheless, Lundgren et al. (2017) question the carapace boundary and, based on an enhanced seismic catalog, showed that the seismic gap does not exist. Conversely, the authors identified a decrease 
of the seismic activity below $4 \mathrm{~km}$ depth, interpreted as the fragile-ductile transition zone controlled by the magmatic heat source.

The mechanism for the development of the volcano-hosted vapor-dominated reservoir is still not fully understood. Since the first model proposed by White et al. (1971), several numerical models have demonstrated that this kind of system evolves from liquid-dominated reservoirs by a drop in the pressure; other complex constraints, like permeability boundaries to heat source and input-output balance, could also be influential (Faust and Mercer 1979; Preuss 1985; Ingebritsen and Sorey 1988; Norton and Hulen 2001; Raharjo et al. 2016). For instance, Allis and Shook (1999) showed that tectonic activity at The Geysers was capable of forming vapor-dominated reservoirs from liquid-pressurized conditions by a uniaxial extension below $1 \mathrm{~km}$ depth. In the case of Copahue, a multi-episodic magmatic injection and its effect on fracture-related permeability might contribute to the steam cap development. InSAR satellite data allowed to identify inflation-deflation cycles related to the volcanic activity at Copahue (Velez et al. 2011, 2016; Lundgren et al. 2017). It is expected that the connectivity of the fracture network will be enhanced in the host rock after each magmatic-related deformation cycle, hence, favoring the permeability and decreasing the local pressure.

The fluid chemistry at vents of the Copahue volcano also reflects the link between deformation processes and permeability enhancement because of a straighter fluid path from the deep source to the surface (Agusto et al. 2012a, b, 2018; Tassi et al. 2017). Morphostructural and volcanic landscape evolution provide further explanations. Moore et al. (2008) speculated based on petrologic evidence that catastrophic pressure reduction related to volcanic flank failure may have triggered the vapor zone at the Telaga Bodas geothermal system. In the case of Copahue, its northeastern flank is structurally controlled showing an NE-trending collapse with the associated eruptive deposits. The lack of precise radiometric dating of those deposits prevents dating this deformation episode, but the collapse of the northeastern flank of the volcano as the trigger for the current geothermal field development should not be ruled out. Additional studies are required to understand the relationship between the volcanic activity and the structurally controlled high permeability zone. This relationship is crucial to assess the evolution of the layered reservoir of the Copahue geothermal system. Further thermomechanical and petrophysical models linked to the fluid geochemical database could assess the effects of the Copahue volcano activity with transient changes at the layered geothermal reservoir.

\section{Conclusions}

The present work aimed to examine the available data of the Copahue geothermal field to understand the critical aspects of its reservoir and obtain a reliable conceptual model. Different sources of information, like high-sulfidation hydrothermal zones, lack of silica sinters and chloride hot springs, a first vapor-single-phase discharge at the exploration wells and results of chemical analysis, lead to several authors to interpret a vapor-dominated reservoir for Copahue geothermal system (Sierra et al. 1992; JICA 1992; Nakanishi et al. 1995; Chiodini et al. 2015). However, this outcome is contrary to the other lines of evidence, like the transition from shallow argillic to deep propylitic alteration zones, gas geothermometers calibrated to near-neutral $\mathrm{pH}$ environment, pressure profiles, and dry 
vapor declination until the feed zone becomes exhausted and low recharge of the feed zone, among others. Nevertheless, described features are consistent with a configuration where a shallow vapor zone caps a deep reservoir driven by a pressurized fluid.

We propose a 1D layered reservoir model for the geothermal resource at Copahue in agreement with the available multiproxy data until date. The key elements of the model are listed below:

- The upper thermal boundary of the reservoir extends until $800 \mathrm{~m}$ depth, including the impermeable clay cap; the available temperature profiles clearly define it.

- The clay cap is characterized by argillic alteration of the andesitic lavas of Las Mellizas Formation, in good agreement with the stilbite zone of Mas et al. (1995). Its low electric resistivity is consistent with the presence of smectite. It is mandatory to perform a magnetotelluric survey to define the extension of this layer.

- We suggest the existence of a shallow steam cap immediately below the clay cap, based on the isolated and nonproductive behavior of this reservoir. This vapor zone has $200-215^{\circ} \mathrm{C}$, low seismic activity, and high electrical resistivity, and is highlighted by the isothermal profiles at the well logs (JICA 1992; Agusto et al. 2013).

- The lower part of the reservoir is subject to controversy because of the lack of direct measurements.

- A transition between the steam cap and a liquid-dominated reservoir might lead to a two-phase reservoir, although its development also depends on the permeability of the host rock, among other constraints.

- We propose a deep liquid-dominated reservoir develops below $1500 \mathrm{~m}$ depth, with a temperature of $\sim 280^{\circ} \mathrm{C}$ and near-neutral $\mathrm{pH}$ condition. This reservoir develops at the Cola de Zorro-Hualcupén Formation, has a pervasive propylitic alteration, and the wairakite + laumontite + chlorite + epidote + prehnite + actinolite is the likely mineral assemblage (JICA 1992). Although geochemical and production data support the assumption of a deep brine level below the upper steam cap, there is no reliable evidence (e.g., direct data) of its existence at the moment.

- The shallow steam zone development is likely consequence of a drastic decrease in pressure. This pressure drop could respond to a permeability enhancement during deflation-inflation cycles, and/or to Pleistocene-to-present tectonic deformation that leads to the collapse of the northeastern flank of the volcano.

- Transient changes of the reservoir layering would be expected given, its direct interaction between the volcanic dynamics, and the hydrothermal-geothermal system.

This work contributes to the existing knowledge of the geothermal resource at Copahue by providing a revision and integrating the available information in a single conceptual model of the reservoir. Although the existence of a deep liquid-dominated reservoir is consistent with the available data, more work involving new deep wells is needed to constrain its physicochemical conditions better. 


\section{Authors' contributions}

$\mathrm{HB}$ was the major contributor in analyzing and writing the manuscript. DY improved several geothermal interpretations and the manuscript. MA analyzed the chemical data. All authors read and approved the final manuscript.

\section{Author details}

1 CONICET-IDEAN, Instituto de Estudios Andinos, Universidad de Buenos Aires, Pabellón II, Nuñez, C1428EHA Buenos

Aires, Argentina. ${ }^{2}$ Facultad de Ciencias Exactas y Naturales, Universidad de Buenos Aires. Intendente Güiraldes, 2160 Ciudad Universitaria-Pabellón II, C1428EHA Buenos Aires, Argentina.

\section{Competing interests}

The authors declare that they have no competing interests.

Availability of data and materials

Data sets analyzed during the current study are included in this article or references.

\section{Publisher's Note}

Springer Nature remains neutral with regard to jurisdictional claims in published maps and institutional affiliations.

Received: 21 September 2018 Accepted: 6 March 2019

Published online: 12 March 2019

\section{References}

Agusto M, Caselli A, Tassi F, Dos Santos Afonso M, Vaselli O. Seguimiento geoquímico de las aguas ácidas del sistema volcán Copahue-Río Agrio: Posible aplicación para la identificación de precursores eruptivos. Revista de la Asociación Geológica Argentina. 2012a;69(4):481-95.

Agusto M, Velez ML, Caselli A, Euillades P, Tassi F, Capaccioni B, Vaselli O. Correlación entre anomalías térmicas, geoquímicas y procesos deflacionarios en el volcán Copahue Actas del Congreso Geologico Chileno, Antofagasta; 2012b.

Agusto M, Tassi F, Caselli AT, Vaselli O, Rouwet D, Capaccioni B, Darrah T. Gas geochemistry of the magmatic-hydrothermal fluid reservoir in the Copahue-Caviahue Volcanic Complex (Argentina). J Volcanol Geother Res. 2013;257:44-56.

Agusto M, Velez M, Euillades P, Tassi F, Caselli A, Lamberti M, Szentiványi J, Llano J, Nogués V, Trinelli A. Correlación entre cambios geoquímicos y deformación en el volcán Copahue (Argentina) durante el ciclo eruptivo 2012-2017 Foro internacional: Los volcanes y su impacto, 31-35. Perú: Arequipa; 2018.

Alamsyah O, Bratakusuma B, Hoang V, Roberts JW. Dynamic modeling of Darajat Field using numerical simulation. In: Proceedings World Geothermal Congress, Antalya Turkey, 2005. p. 24-29.

Allis R, Shook M. An alternative mechanism for the formation of The Geyser vapor-dominated reservoir. Proceedings, 24th Workshop on Geothermal Reservoir Engineering. Stanford: Stanford University; 1999. p. 53-63.

Allis R. Insight on the formation of vapor-dominated geothermal system. In: Proceedings of the World Geothermal Congress, Kyushu-Tohoku, 2000. p. 2489-96.

Aravena D, Munoz M, Morata D, Lahsen A, Parada MA, Dobson P. Assessment of high enthalpy geothermal resources and promising areas of Chile. Geothermics. 2016;59:1-13.

Arnórsson S. Isotopic and chemical techniques in geothermal exploration, development and use. Vienna: International Atomic Energy Agency; 2000, p. 109-111. ISBN 92-0-101600-X

Batini F, Brogi A, Lazzarotto A, Liotta D, Pandeli E. Geological features of Larderello-Travale and Mt Amiata geothermal areas (southern Tuscany, Italy). Episodes. 2003;26(3):239-44.

Bellani S, Brogi A, Lazzarotto A, Liotta D, Ranalli G. Heat flow, deep temperatures and extensional structures in the Larderello Geothermal Field (Italy): constraints on geothermal fluid flow. J Volcanol Geotherm Res. 2004;132(1):15-29.

Boden DR. Geologic fundamentals of geothermal energy. Boca Raton: CRC Press; 2016.

Bogie I, Kusumah YI, Wisnandary MC. Overview of the Wayang Windu geothermal field. Geothermal. 2008;37:347-65.

Bogie I, Ussher G, Lovelock B, Mackenzie K. Finding the productive sweet spots in the vapour and transitional vapour-liquid dominated geothermal fields of Java, Indonesia. In: Proceedings world geothermal Congress. 2015.

Borzotta E, Caselli AT, Mamani MJ. Magma Chamber Associated to Deep Faults in Copahue Active Volcanic Complex, South America, Suggested by Magnetotelluric Study. Geofizicheskiy Zhurnal. 2018;40(4):178-90.

Caselli A, Agusto M, Vélez ML, Forte P, Bengoa C, Daga R, Albite JM, Capaccioni B. The 2012 eruption En: Tassi, F, Vaselli, O y Caselli, A (eds) Copahue Volcano Springer, Active Volcanoes of the world 4: 61-77, Berlin-Heidelberg; 2015.

Cembrano J, Lara L. The link between volcanism and tectonics in the southern volcanic zone of the Chilean Andes: a review. Tectonophysics. 2009;471(1-2):96-113.

Chiodini G, Cioni R, Marini L. Reactions governing the chemistry of crater fumaroles from Vulcano Island, Italy, and implications for volcanic surveillance. Appl Geochem. 1993;8(4):357-71.

Chiodini G, Brombach T, Caliro S, Cardellini C, Marini L, Dietrich V. Geochemical indicators of possible ongoing volcanic unrest at Nisyros Island (Greece). Geophys Res Lett. 2002;29(16):6.

Chiodini G, Cardellini C, Lamberti MC, Agusto M, Caselli A, Liccioli C, Caliro S. Carbon dioxide diffuse emission and thermal energy release from hydrothermal systems at Copahue-Caviahue Volcanic Complex (Argentina). J Volcanol Geotherm Res. 2015;304:294-303.

Chiodini G, Marini L. Hydrothermal gas equilibria: the $\mathrm{H}_{2} \mathrm{O}-\mathrm{H}_{2}-\mathrm{CO}_{2}-\mathrm{CO}-\mathrm{CH}_{4}$ system. Geochimica et Cosmochimica Acta. 1998;62:2673-87.

Corbett GJ, Leach TM. A guide to pacific rim Au/Cu exploration. A workshop presented in Jakarta, Indonesia 14-15 December 1993, 82 p.

Cumming W, Mackie R. MT survey for resource assessment and environmental mitigation at the Glass Mountain KGRA. California Energy Commission, GRDA Geothermal Resources Development Account Report. 2007. 
D'Amore F, Panichi C. Evaluation of deep temperatures of hydrothermal system by a new gas geothermometer. Geochim Cosmochim Acta. 1980;44:549-56.

D'Amore F, Truesdell AH. Calculation of geothermal reservoir temperatures and steam fractions from gas compositions. GRC Symp Geotherm Energy. 1985;9:303-10.

Della Vedova B, Vecellio C, Bellani S, Tinivella U. Thermal modeling of the Larderello geothermal field (Tuscany, Italy). Int J Earth Sci. 2008;97(2):317-32.

Delpino D, Bermúdez A. La actividad del volcán Copahue durante 1992 Erupción con emisión de azufre piroclástico Provincia de Neuquén $12^{\circ}$ Congreso Geológico Argentino, Actas. 1993; vol. 4, p. 292-301, Mendoza.

Delpino D, Bermúdez A. La erupción del volcán Copahue del año 2000 Impacto social y al medio natural Provincia del Neuquén Argentina $15^{\circ}$ Congreso Geológico Argentino, Actas 2002; vol. 3, p. 365-70, El Calafate.

Dickinson WR, Snyder WS. Geometry of triple junctions related to San Andreas transform. J Geophys Res. 1979;84(B2):561-72.

DiPippo R. Geothermal power plants: principles, applications, case studies and environmental impact. New York: Butterworth-Heinemann; 2016.

Elder W, Moore J (2016) Geology of geothermal resources. In: Geothermal Power Generation, Dippipo, R, p. 7-32.

Faust CR, Mercer JW. Geothermal reservoir simulation: 2 Numerical solution techniques for liquid-and vapor-dominated hydrothermal systems. Water Resour Res. 1979;15(1):31-46.

Folguera A, Rojas Vera E, Vélez L, Tobal J, Orts D, Agusto M, Caselli A, Ramos V. A review of the Geology, Structural Controls, and Tectonic Setting of Copahue Volcano, Southern Volcanic Zone, Andes, Argentina In Copahue Volcano, Tassi, F, Vaselli, O, Caselli, A, 2016, p. 3-22.

Gambill DT, Beraquit DB. Development history of the Tiwi geothermal field. Philippines Geotherm. 1993;22(5-6):403-16.

Gaviria Reyes MA, Agusto MR, Trinelli MA, Caselli AT, Dos Santos AM, Calabrese S. Estudio hidrogeoquímico de las áreas termales del complejo volcánico Copahue-Caviahue Revista de la Asociación. Geológica Argentina. 2016;73(2):256-69.

Gifkins C, Herrmann W, Large R. Altered volcanic rocks - a guide to description and interpretation Centre Ore Depos Res. Hobart: Univ Tasmania; 2005.

Giggenbach WF. Redox processes governing the chemistry of fumarolic gas discharges from White Island. N Z Appl Geochem. 1987;2:143-61.

Giggenbach WF. Chemical techniques in geothermal exploration. In: Application of geochemistry in geothermal reservoir development. New York: UNITAR; 1991, p. 253-273.

Giggenbach WF. Relative importance of thermodynamic and kinetic processes in governing the chemical and isotopic composition of carbon gases in high heat flow sedimentary basins. Geochim Cosmochim Acta. 1997;61:3763-85.

González-Partida E, Carrillo-Chávez A, Levresse G, Tello-Hinojosa E, Venegas-Salgado S, Ramirez-Silva G, Camprubi A. Hydro-geochemical and isotopic fluid evolution of the Los Azufres geothermal field, Central Mexico. Appl Geochem. 2005;20(1):23-39.

Grant MA, Bixley PF. Geothermal reservoir engineering. 2nd ed. New York: Elsevier Inc; 2011.

Gunderson R, Cumming W, Astra D, Harvey C. Analysis of smectite clays in geothermal drill cuttings by the methylene blue method: for well site geothermometry and resistivity sounding correlation. In: Proceedings of the 2000 world geothermal congress, Tokyo, Japan; 2000. p. 1175 e81.

Hanano M, Matsuo Gl. Initial state of the Matsukawa geothermal reservoir: reconstruction of a reservoir pressure profile and its implications. Geothermics. 1990;19(6):541-60

Hedenquist JW, Arribas A, Gonzalez-Urien E. Exploration for epithermal gold deposits. Rev Econ Geol. 2000;13(2):45-77.

Hedenquist JW, Reyes AG, Simmons SF, Taguchi S. The thermal and geochemical structure of geothermal and epithermal systems: a framework for interpreting fluid inclusion data. Eur J Mineral. 1992;4:989-1015.

Heise W, Caldwell TG, Bibby HM, Bannister SC. Three-dimensional modeling of magnetotelluric data from the Rotokawa geothermal field, Taupo Volcanic Zone, New Zealand. Geophys J Int. 2008;173(2):740-50.

Henley RW, Hedenquist JW, Roberts PJ, editors. Guide to the Active Epithermal (Geothermal) Systems and Precious Metal Deposits of New Zealand Gebruder Borntraeger, Monograph Series on Mineral Deposits, 26, 1986.

Henley RW, Ellis AJ. Geothermal systems, ancient and modern. Earth Sci Rev. 1983;19:1-50.

Hochstein MP, Sudarman S. History of geothermal exploration in Indonesia from 1970 to. Geothermics. 2000;37:220-66.

Ingebritsen SE, Sorey ML. Vapor-dominated zones within hydrothermal systems: evolution and natural state. J Geophys Res. 1988;93(B11):13635-55.

Iriarte S. Jornada Geotérmica Universidad de Concepción, Exploración geotérmica proyecto Tolhuaca. 2013.

JICA. The feasibility study on the Northem Neuquén Geothermal Development Project Ente Provincial de Energía de la Provincia del Neuquén, JICA-EPEN (unpublished), 89 p, Neuquén, 1992.

Jolie E, Moeck I, Faulds JE. Quantitative structural-geological exploration of fault-controlled geothermal systems—a case study from the Basin-and-Range Province, Nevada (USA). Geothermics. 2015;54:54-67.

Jurío RL. Características geoquímicas de los fluidos termales de Copahue (Neuquén, Argentina). Principales implicancias geotérmicas Minería. 1977;172:1-11.

Katili JA. Volcanism and plate tectonics in the Indonesian island arcs. Tectonophysics. 1975;26(3-4):165-88.

Kiseleva I, Navrotsky A, Belitsky IA, Fursenko BA. Thermochemistry and phase equilibria in calcium zeolites. Am Miner. 1996;81(5-6):658-67.

Layman E, Soemarinda S. The Patuha vapor-dominated resource West Java Indonesia. In: Proceedings, 28th workshop on geothermal reservoir engineering, Stanford University, 2003.

Lazo J, Basualto D, Bengoa C, Cardona C, Franco L, Gil-Cruz F, Morales S. Spatial Distribution of b-value of the Copahue volcano during the 2012-2014 eruptive period: Relationship between magmatic and hydrothermal system. In: EGU General Assembly Conference Abstracts (Vol 17), 2015.

Liou JG. P-T stabilities of Laumontite, Wairakite, Lawsonite, and related minerals in the system $\mathrm{CaAl}_{2} \mathrm{Si}_{2} \mathrm{O}_{8}-\mathrm{SiO}_{2}-\mathrm{H}_{2} \mathrm{O}$. J Petrol. 1971;12(2):379-411.

Lundgren P, Nikkhoo M, Samsonov SV, Milillo P, Gil-Cruz F, Lazo J. Source model for the Copahue volcano magma plumbing system constrained by InSAR surface deformation observations. J Geophys Res. 2017;122(7):5729-47. 
Mamani MJ, Borzotta E, Venencia JE, Maidana A, Moyano CE, Castiglione B. Electric structure of the Copahue Volcano (Neuquén Province, Argentina), from magnetotelluric soundings: 1D and 2D modellings. J South Am Earth Sci. 2000;13(1-2):147-56.

Martini M, Bermúdez A, Delpino D, Giannini L. The thermal manifestations of Copahue volcano area. Neuquén, Argentina. In: Congreso Geológico Chileno 1997, p. 352-6.

Mas GR, Mas LC, Bengochea L. Inclusiones fluidas en el pozo exploratorio COP-3, campo geotérmico de Copahue, Provincia del Neuquén, Argentina. In: XII Congreso Geológico Argentino, Mendoza. 1993, p. 92-8.

Mas GR, Mas LC, Bengochea L. Zeolite zoning in drill holes of the Copahue geothermal field, Neuquén, Argentina. In: Proceedings of the World Geothermal Congress. 1995. p. 1077-81.

Mas GR, Mas LC, Bengochea L. Hydrothermal, surface alteration in the Copahue geothermal field (Argentina). In: Proceedings twenty-fifth workshop on geothermal reservoir engineering, Stanford University Stanford, California. 1996, p. 22-4.

Mas LC, Mas GR, Bengochea L. Heat flow of Copahue geothermal field, its relation with tectonic scheme. In: Proceedings of world geothermal congress, Tohoku, Japan. 2000, p. 1419-24.

Melosh G, Cumming W, Benoit D, Wilmarth M, Colvin A, Winick J, Peretz A. Exploration results and resource conceptual model of the Tolhuaca Geothermal Field, Chile. In: Proceedings, World Geothermal Congress, 2010.

Melosh G, Moore J, Stacey R. Natural reservoir evolution in the Tolhuaca geothermal field, southern Chile. In: Proceedings 36th workshop on geothermal reservoir engineering, Stanford University, Stanford, CA. 2012.

Moeck IS. Catalog of geothermal play types based on geologic controls. Renew Sustain Energy Rev. 2014;37:867-82.

Monterrosa M, López FEM. Sustainability analysis of the Ahuachapán geothermal field: management and modeling. Geothermics. 2010;39(4):370-81.

Moore JN, Allis RG, Nemcok M, Powell TP, Bruton CJ, Wannamaker PE, Raharjo IB, Norman DN. The evolution of volcanohosted geothermal systems based on deep wells from Karaha-Telaga Bodas, Indonesia. Am J Sci. 2008;308:1-48.

Nakanishi S, Abe M, Todaka N, Yamada M, Sierra JL, Gingins MO, Pedro GE. Copahue geothermal system, Argentinastudy of a vapor-dominated reservoir In Proceedings World Geothermal Congress '95, Florence, 1995. p. 18-31.

Naranjo JA, Polanco E. The 2000 AD eruption of Copahue Volcano, Southern Andes. Revista Geológica de Chile. 2004;31:279-92

Nicholson K. Geothermal fluids, 1993. p. 263.

Norton DL, Hulen JB. Preliminary numerical analysis of the magma-hydrothermal history of The Geysers geothermal system, California, USA. Geothermics. 2001;30(2):211-34.

Ozima M, Podosek FA. Noble gas geochemistry. Cambridge: Cambridge University Press; 2002.

Panarello HO. Características isotópicas y termodinámicas de reservorio del campo geotérmico Copahue-Caviahue, provincia del Neuquén. Revista de la Asociación geológica Argentina. 2002:57(3):328-40.

Pérez-Flores P, Cembrano J, Sánchez-Alfaro P, Veloso E, Arancibia G, Roquer T. Tectonics, magmatism and paleo-fluid distribution in a strike-slip setting: insights from the northern termination of the Liquiñe-Ofqui fault System. Chile Tectonophys. 2016;680:192-210.

Pesce A. Evolución volcano-tectónica del complejo efusivo Copahue-Caviahue y su modelo geotérmico preliminar. Revista de la Asociación Geológica Argentina. 1989:44:307-27.

Petrinovic I, Villarosa G, D’Elía L, Guzman S, Paez G, Outes V, Manzoni C, Delmenico A, Balbis C, Carniel R, Hernando I. La erupción del 22 de diciembre de 2012 del volcán Copahue, Neuquén, Argentina: Caracterización del ciclo eruptivo y sus productos. Revista de la Asociación Geológica Argentina. 2014;71:161-73.

Pinti DL, Castro MC, Shouakar-Stash O, Tremblay A, Garduño VH, Hall CM, Hélie JF, Ghaleb B. Evolution of the geothermal fluids at Los Azufres, Mexico, as traced by noble gas isotopes, 8180 , 8D, $813 \mathrm{C}$ and $87 \mathrm{Sr} / 86 \mathrm{Sr}$. J Volcanol Geotherm Res. 2013:249:1-11.

Pirajno F. Hydrothermal processes associated with meteorite impacts. In: Hydrothermal processes and mineral systems. Springer: Dordrecht; 2009.

Pratama HB, Saptadji NM. Numerical simulation for natural state of two-phase liquid dominated geothermal reservoir with steam cap underlying brine reservoir In: IOP conference series: earth and environmental science. IOP Publishing: Briston; 2016, vol. 42(1), p. 012006.

Preuss K. A quantitative model of vapor-dominated geothermal reservoirs as heat pipes in fractured porous rocks. Geotherm Resour Coun Trans. 1985;9:353-61.

Raharjo IB, Allis RG, Chapman DS. Why are the only volcano-hosted vapor-dominated geothermal systems in West Java, Indonesia? In Geothermal Resources Council Annual Meeting 2012-Geothermal: Reliable. Global, GRC: Renewable; 2012.

Raharjo IB, Allis RG, Chapman DS. Volcano-hosted vapor-dominated geothermal systems in permeability space. Geothermics. 2016;62:22-32

Ramos $V$, Folguera A. Tectonic evolution of the Andes of Neuquén: constraints derived from the magmatic arc and foreland deformation In Spalletti L, Veiga G, Schwarz E, Howell A (eds.) The Neuquén Basin: A case study in sequence stratigraphy and basin dynamics The Geological Society, Special Publications. 2005. 252: 15-35, London.

Rejeki S, Hadi J, Suhayati I (2005) Porosity study for detail reservoir characterization in Darajat geothermal field, West Java, Indonesia In Proc World Geothermal Congress 2005, Antalya, Turkey, 24-29 April.

Rejeki S, Rohrs D, Nordquist G, Fitriyanto A. Geologic conceptual model update of the Darajat geothermal field Indonesia Proceedings. Paper: World Geothermal Congress; 2010. p. 1283.

Roulleau E, Tardani D, Sano Y, Takahata N, Vinet N, Bravo F, Sanchez J. New insight from noble gas and stable isotopes of geothermal/hydrothermal fluids at Caviahue-Copahue Volcanic Complex: boiling steam separation and waterrock interaction at shallow depth. J Volcanol Geoth Res. 2016;328:70-83.

Sanchez-Alfaro P, Reich M, Arancibia G, Pérez-Flores P, Cembrano J, Driesner T, Tardani D. Physical, chemical and mineralogical evolution of the Tolhuaca geothermal system, southern Andes, Chile: insights into the interplay between hydrothermal alteration and brittle deformation. J Volcanol Geotherm Res. 2016;324:88-104.

Schlüter HU, Gaedicke C, Roeser HA, Schreckenberger B, Meyer H, Reichert C, Prexl A. Tectonic features of the southern Sumatra-western Java forearc of Indonesia. Tectonics. 2002;21(5):1047. 
Sepúlveda F, Dorsch K, Lahsen A, Bender S, Palacios C. The chemical and isotopic composition of geothermal discharges from the Puyehue-Cordón Caulle area (405̊), Southern Chile. Geothermal. 2004;33(5):655-73.

Sepúlveda F (2006) El sistema geotérmico de Cordón Caulle, sur de Chile: caracterización geológica y geoquímica Unpublished PhD thesis (Universidad de Chile).

Shibuya A, Tetsuro M, Shinada S, Yoshioka H (2000) Exploration of Geothermal Zone in Mt Aso West Area in Kyushu, Japan. In: Proceedings of the World Geothermal Congress. p. 1737-41.

Sierra J, D'Amore F, Panarello H, Pedro G (1992) Reservoir characteristics of the vapour dominated geothermal field of Copahue, Neuquén, Argentina, as established by isotopic and geochemical techniques Geothermal Investigations with Isotope and Geochemical Techniques in Latin America. In: Proceedings of Nuclear Techniques in Geothermal Resources Investigation, San José, Costa Rica. p. 13-30.

Stelling P, Shevenell L, Hinz N, Coolbaugh M, Melosh G, Cumming W. Geothermal systems in volcanic arcs: volcanic characteristics and surface manifestations as indicators of geothermal potential and favorability worldwide. JVolcanol Geoth Res. 2016;324:57-72.

Tardani D, Reich M, Roulleau E, Takahata N, Sano Y, Péres-Flores P, Sànchez-Alfaro P, Cembrano J, Arancibia G. Exploring the structural controls on helium, nitrogen and carbon isotopes signatures in hydrothermal fluids along an intraarc fault system. Geochim Cosmochim Acta. 2016;184:193-211.

Tassi F, Agusto M, Lamberti C, Caselli AT, Pecoraino G, Caponi C, Vaselli O. The 2012-2016 eruptive cycle at Copahue volcano (Argentina) versus the peripheral gas manifestations: hints from the chemical and isotopic features of fumarolic fluids. Bull Volcanol. 2017;79(10):69.

Terada A, Sudo Y. Thermal activity within the western-slope geothermal zone of Aso volcano, Japan: development of a new thermal area. Geothermics. 2012;42:56-64.

Terceros ZD, Colorda-ENDE (2000) UCL State of the geothermal resources in Bolivia: Laguna Colorada project. In: Proceedings of the World Geothermal Congress 2000. p. 153-8.

Thain IA, Carey B. Fifty years of geothermal power generation at Wairakei. Geothermics. 2009;38(1):48-63.

Vargas LS, Püschel-Lovengreen S. Analysis of geothermal power plant performance in the context of the Chilean electricity market. In: Proceedings 38th New Zealand Geothermal Workshop. 2016; vol 23, p. 25.

Velez ML, Euillades P, Caselli A, Blanco M, Díaz JM. Deformation of Copahue volcano: inversion of InSAR data using a genetic algorithm. J Volcanol Geoth Res. 2011;202(1-2):117-26.

Velez L, Euillades P, Blanco M, Euillades L. Ground deformation between 2002 and 2013 from InSAR observations Copahue VOlcano, Springer, 2016. p. 175-98.

Villarroel Camacho DG. Geothermal development in Bolivia United Nations University, Geothermal Training Programme. 2014.

White NC, Hedenquist JW. Epithermal gold deposits: styles, characteristics, and exploration Society of Economic Geologists. Newsletter. 1995;23(1):9-13.

White DE, Muffler LJP, Truesdell AH. Vapor-dominated hydrothermal systems compared with hot-water systems. Econ Geol. 1971;66(1):75-97.

Zapata T, Brissón I, Dzelalija F. The role of basement in the Andean fold and thrust belt of the Neuquén Basin. Thrust Tectonics. 1999;99:122-4.

Zarrouk SJ, Moon H. Efficiency of geothermal power plants: a worldwide review. Geothermics. 2014;51:142-53.

\section{Submit your manuscript to a SpringerOpen ${ }^{\circ}$ journal and benefit from:}

- Convenient online submission

- Rigorous peer review

- Open access: articles freely available online

- High visibility within the field

- Retaining the copyright to your article

Submit your next manuscript at $\boldsymbol{\Delta}$ springeropen.com 